\title{
Pengaruh Progressive Muscle Relaxation dan Logoterapi terhadap Kecemasan, Depresi, dan Kemampuan Relaksasi
}

\author{
Duma Lumban Tobing ${ }^{1}$, Budi Anna Keliat ${ }^{2}$, Ice Yulia Wardhani² \\ ${ }^{1}$ Fakultas Ilmu Kesehatan Universitas Pembangunan Nasional "Veteran" Jakarta, ${ }^{2}$ Fakultas Ilmu \\ Keperawatan Universitas Indonesia \\ E-mail: duma.yosephine76@gmail.com
}

\begin{abstract}
Abstrak
Kanker merupakan penyakit kronis yang mengancam kehidupan. Kanker dianggap sebagai satu stresor yang dapat menimbulkan masalah psikologis. Masalah psikologis yang paling banyak ditemukan pada klien kanker adalah kecemasan dan depresi. Kecemasan dan depresi yang dialami klien kanker bukan hanya berdampak pada kualitas hidup, juga berdampak pada pengobatan yang dilakukan, memperpanjang waktu hospitalisasi dan menimbulkan efek negatif pada prognosis serta ketahanan hidup klien. Penelitian ini bertujuan untuk mengidentifikasi pengaruh terapi progressive muscle relaxation (PMR) dan logoterapi terhadap kecemasan dan depresi, kemampuan relaksasi dan kemampuan memaknai hidup klien kanker. Penelitian ini menggunakan desain kuasi eksperiman pretestposttest with control group dengan jumlah sampel 90 orang klien kanker yang dibagi dalam dua kelompok intervensi dan 1 kelompok kontrol. Hasil penelitian menunjukkan bahwa kecemasan menurun secara bermakna $p=0.00(p<$ $0.05 ; \alpha=0.05)$; depresi menurun secara bermakna $p=0.002(p<0.05 ; \alpha=0.05)$; kemampuan relaksasi meningkat secara bermakna $p=0.00(p<0.05 ; \alpha=0.05)$; dan kemampuan memaknai hidup meningkat secara bermakna $p=0.01$ $(p<0.05 ; \alpha=0.05)$ pada kelompok yang mendapatkan PMR dan logoterapi. Terapi PMR dan logoterapi disarankan sebagai terapi keperawatan lanjutan dalam merawat klien kanker yang mengalami kecemasan dan depresi.
\end{abstract}

Kata kunci: Ansietas, depresi, klien kanker, progressive muscle relaxation.

\section{Effect of Progressive Muscle Relaxation and Logotherapy on Anxiety, Depression, and Relaxation Ability}

\begin{abstract}
Cancer is a chronic disease that threaten human life. Cancer regarded as a stressor that can cause psychological problems. The most commonly psychological problem found on the cancer client are anxiety and depression which will affect on quality of life, impact on treatment performed, prolong hospitalization and have a negative effect on prognosis and the survival of client. This research aimed to determine the therapeutic effect of Progressive Muscle Relaxation (PMR) and Logotherapy against anxiety and depression, relaxation ability and ability to interpret life. This study used quasi-experimental design pretest-posttest control group with a sample of 90 people cancer clients who were divided into two intervention groups and one control group. The results showed that anxiety decreased significantly $p=0.00(p<0.05 ; \alpha=0.05)$; depression decreased significantly $p=0.002(p<0.05 ; \alpha=0.05)$; ability relaxation increased significantly $p=0.00(p<0.05 ; \alpha=0.05)$; and the ability to make sense of life increased significantly $p=0.01(p<0.05 ; \alpha=0.05)$ in the group receiving PMR and Logotherapy. PMR therapy and Logotherapy are recommended as advanced nursing therapy in treating cancer clients who experience anxiety and depression.
\end{abstract}

Key words: Anxiety, depression, client cancer, progressive muscle relaxation. 
Duma Lumban Tobing: Pengaruh Progressive Muscle Relaxation dan Logoterapi

\section{Pendahuluan}

Kanker merupakan penyakit yang memiliki konotasi menakutkan dan identik dengan kematian. Jumlah penderita kanker di dunia mencapai 12 juta orang tiap tahun, dan 7,6 juta diantaranya meninggal. World Health Organization (WHO) pada tahun 2011 memperkirakan bahwa penderita kanker pada tahun 2030 akan mencapai 26 juta orang dan 17 juta diantaranya meninggal jika tidak dikendalikan. Kanker merupakan penyebab kematian kedua setelah penyakit kardiovaskuler. Maka tak heran jika kanker identik dengan kematian.

Diagnosis kanker bagi klien merupakan stresor yang besar yang dapat menimbulkan respon psikologis dan emosional bagi klien dan keluarganya. Respon psikologis muncul bervariasi, mulai dari rasa takut terutama akan kematian, cemas, depresi, marah, tidak percaya, penyangkalan, irritable, anoreksia, insomnia, lelah, putus asa sampai dengan keinginan untuk bunuh diri (Djoerban \& Shatri, 2007). Cemas muncul berkaitan dengan adanya ketidakpastian (uncertainty) akan prognosis penyakit, efektifitas pengobatan terhadap pemulihan kondisi yang sering ditemukan pada pasien-pasien kanker terutama stadium lanjut (Otto, 2007). Mynatt dan Cunningham (2007) menyatakan bahwa penyebab kecemasan berkaitan dengan diagnosis kanker, pemeriksaan diagnostik yang dilakukan dan pengobatan yang dijalani. Penyebab lain kecemasan menurut Djoerban dan Shatri (2007) adalah persepsi klien dan keluarga tentang kanker yang selalu dikaitkan dengan kematian, masalah ketidakpastian setelah pengobatan yang dilakukan dan ketakutan akan kanker menjadi progresif atau kambuh kembali.

Depresi pada klien kanker berkaitan dengan ketakutan akan kematian, tidak bisa meneruskan rencana-rencana hidupnya, perubahan citra diri, percaya diri, perubahan peran sosial dan gaya hidup serta masalah -masalah terkait finansial dan dampak fisik yang dialami akibat penyakit dan pengobatan yang dilakukan (Konginan, 2008). Penyebab lain menurut Mhaidat, Alzoubi, Al-Sweedan, dan Alhusein (2009) adalah diagnosis, stadium dan jenis kanker, sedangkan menurut Jim, Purnell, Richardson, Kreutz, dan Andersen
(2007) dan So, Marrsh, Ling, Lo, Yeung, dan Li (2011) penyebab depresi adalah penatalaksanaan pengobatan yang dilakukan. Spiegel dan Davis (2002) menyatakan bahwa insiden kecemasan dan depresi meningkat sejalan dengan keparahan penyakitnya gejala yang muncul seperti nyeri kronis dan kelelahan. Dampak depresi pada penderita kanker berupa percobaan bunuh diri yang dijumpai pada hampir 1/3 dari penderita kanker yang mengalami depresi major dan $>50 \%$ dengan gangguan penyesuaian, penelantaran diri dimana penderita menjadi tidak kooperatif, baik dalam hal pengobatan maupun menjaga stamina dan munculnya distres pada keluarga. Kondisi ini akan semakin memperparah penyakitnya dan pada akhirnya akan menurunkan kualitas hidup penderita.

Intervensi keperawatan sangat diperlukan untuk dapat menurunkan kecemasan dan depresi. Progressive Muscle Relaxation (PMR) dan Logoterapi merupakan bentuk terapi keperawatan spesialis yang dapat diberikan pada klien kanker untuk mengurangi kecemasan dan depresi. Brem dan Kumar (2011) menyatakan bahwa PMR adalah suatu bentuk terapi relaksasi yang dapat diberikan pada klien kanker untuk mengurangi kecemasan dan depresi. Kondo, dkk., (2009) menyatakan bahwa terapi PMR memberikan efek relaksasi pada klien kanker yang mengalami kecemasan, selain itu Cheung, Chinn, dan Pascual (2003) juga menunjukkan hasil PMR dapat menurunkan tingkat kecemasan dan meningkatkan kualitas hidup pada klien kanker kolerektal dengan pemasangan stoma.

Logoterapi adalah bentuk psikoterapi yang digunakan pada klien kanker untuk menemukan makna hidup dalam penderitaan yang dialaminya (Jahoda, 2000). Terapi ini dapat melihat individu secara holistik yang meliputi gambaran diri, kepercayaan diri, kemampuan individu dalam mengatasi stres, dan menemukan makna hidup (Marshall, 2011). Terapi ini dapat diberikan pada klien dengan kondisi penyakit terminal, penyakit kronik, post traumatic stress disorder(PTSD), ketergantungan alkohol, berduka, depresi, gangguan kepribadian, obsessive compulsive disorder, dan fobia (Bastaman, 2007 \& Lanzt, 1998). Kyung, dkk., (2009) menunjukkan 
Duma Lumban Tobing: Pengaruh Progressive Muscle Relaxation dan Logoterapi

hasil logoterapi sangat bermanfaat untuk meningkatkan kualitas hidup pasien kanker terminal. Hal ini menunjukkan bahwa logoterapi dapat digunakan sebagai satu terapi spesialis pada pasien dengan penyakit kronis, termasuk kanker. Penelitian ini menggunakan kombinasi terapi PMR dan logoterapi untuk menurunkan kecemasan dan depresi yang dialami oleh klien dengan kanker.

\section{Metode Penelitian}

Penelitian ini menggunakan desain penelitian "Quasi Experimental Pre-Post Test With Control Group" dengan intervensi terapi PMR dan logoterapi. Teknik pengambilan sampel penelitian menggunakan purposive sampling dengan jumlah total sampel sebanyak 90 orang yang dibagi dalam dua kelompok intervensi dan satu kelompok kontrol. Masing-masing kelompok berjumlah 30 orang. Sampel dipilih berdasarkan kriteria inklusi, yaitu berusia 18-65 tahun, bersedia jadi responden, memiliki diagnosis kecemasan dan depresi, kesadaran compos mentis, dapat berbahasa Indonesia dengan baik, mampu membaca dan menulis. Selanjutnya peneliti akan melakukan screening kecemasan dan depresi dengan menggunakan kuesioner pengukuran kecemasan dan depresi Hospital Anxiety Depression Scale (HADS) Jika terdapat skor $\geq 8$, klien akan dilibatkan sebagai responden dalam penelitian ini.

Instrumen penelitian ini menggunakan kuesioner yang terdiri dari data karekteristik responden yang meliputi: usia, jenis kelamin, pekerjaan, tingkat pendidikan, status pernikahan, penghasilan, lama sakit, jenis kanker, dan pengobatan yang dilakukan. Data kecemasan dan depresi klien kanker menggunakan HADS dengan mengategorikan kecemasan dan depresi rendah dengan skor 0-14, kecemasan dan depresi sedang dengan skor 15-27 serta kecemasan dan depresi tinggi dengan skor 28-42. Instrumen pengukuran kemampuan relaksasi dengan mengategorikan kemampuan psikomotor memiliki nilai minimal 0 dan maksimal 39, dengan rentang rendah $0-13$, sedang 14-25, dan tinggi 26-39. Instrumen pengukuran kemampuan memaknai hidup dengan kategori rendah: 0-21, sedang 21-39, dan tinggi 40-60. Instrumen sudah dilakukan uji validitas dan reliabilitas dengan hasil 0.908 untuk instrumen HADS, 0.770 untuk kemampuan relaksasi, dan 0.951 untuk instrumen kemampuan memaknai hidup.

Penelitian ini dilaksanakan selama lima minggu. Peneliti dibantu oleh seorang kolektor data dengan latar belakang Ners dan telah mendapatkan pelatihan tentang petunjuk pengisian kuesioner, menjelaskan isi dari masing-masing butir pertanyaan dan, cara pengumpulan kuesioner. Pada tahap intervensi, peneliti memberikan intervensi kepada responden pada kelompok intervensi 1 berupa terapi PMR yang terdiri dari tiga sesi dan logoterapi yang terdiri dari empat sesi. Pada kelompok intervensi 2 diberikan logoterapi yang terdiri dari 4 sesi. Sementara kelompok kontrol hanya diberikan bookleet yang berisi tentang terapi generalis untuk mengatasi kecemasan dan depresi. Pada kelompok intervensi yang diberikan terapi PMR dan logoterapi, waktu pelaksanaan setiap sesinya berlangsung selama 30 menit dan dilakukan pertemuan sebanyak $5 \mathrm{kali}$ pada tiap klien. Pada pertemuan pertama dilakukan pretest kemampuan klien, kemudian pada pertemuan kedua dilakukan pemberian terapi PMR sesi 1 dan 2 serta logoterapi sesi 1 dan 2. Pada pertemuan ketiga dilanjutkan PMR sesi 3 dan logoterapi sesi 3 dan 4 . Pertemuan keempat adalah evaluasi latihan mandiri klien dan pertemuan kelima dilakukan posttest.

Pada kelompok intervensi yang diberikan logoterapi, waktu pelaksanaan setiap sesinya berlangsung selama 30 menit dan dilakukan pertemuan sebanyak 4 kali pada tiap klien. Pada pertemuan pertama dilakukan pretest kemampuan klien, kemudian pada pertemuan kedua dilakukan pemberian logoterapi sesi 1 dan 2. Pada pertemuan ketiga dilanjutkan logoterapi sesi 3 dan 4. Pertemuan keempat adalah evaluasi latihan mandiri klien dan pertemuan kelima dilakukan posttest. Analisis statistik yang dipergunakan yaitu univariat dan bivariat dengan analisis paired-t test dan Anova.

\section{Hasil Penelitian}

Penelitian ini telah dilakukan pada 90 orang klien kanker yang terbagi menjadi tiga kelompok yaitu 30 orang klien kelompok 
Duma Lumban Tobing: Pengaruh Progressive Muscle Relaxation dan Logoterapi

Tabel 1 Distribusi dan Analisis Kesetaraan Karekteristik Jenis Kelamin, Pendidikan, Pekerjaaan, Status pernikahan, Penghasilan Keluarga, Jenis Kanker, dan Pengobatan Klien Kanker

\begin{tabular}{|c|c|c|c|c|c|c|c|c|c|}
\hline \multirow[t]{2}{*}{ Karakteristik } & \multicolumn{2}{|c|}{$\begin{array}{c}\text { Kelompok } \\
\text { Intervensi } 1 \\
\quad(\mathbf{n}=\mathbf{3 0}) \\
\end{array}$} & \multicolumn{2}{|c|}{$\begin{array}{c}\text { Kelompok } \\
\text { Intervensi } 2 \\
(\mathbf{n}=\mathbf{3 0}) \\
\end{array}$} & \multicolumn{2}{|c|}{$\begin{array}{c}\text { Kontrol } \\
(n=30)\end{array}$} & \multicolumn{2}{|c|}{$\begin{array}{c}\text { Total } \\
(n=90)\end{array}$} & \multirow[t]{2}{*}{$\begin{array}{c}P \\
\text { value }\end{array}$} \\
\hline & $\mathrm{n}$ & $\%$ & $\mathrm{n}$ & $\%$ & $\mathbf{n}$ & $\%$ & $n$ & $\%$ & \\
\hline $\begin{array}{l}\text { Jenis Kelamin } \\
\text { Laki-laki } \\
\text { Perempuan }\end{array}$ & $\begin{array}{l}11 \\
19\end{array}$ & $\begin{array}{l}36,4 \\
63,3\end{array}$ & $\begin{array}{l}12 \\
18\end{array}$ & $\begin{array}{l}40 \\
60\end{array}$ & $\begin{array}{l}19 \\
11\end{array}$ & $\begin{array}{l}63,3 \\
36,7\end{array}$ & $\begin{array}{l}42 \\
48\end{array}$ & $\begin{array}{l}46,7 \\
53,3\end{array}$ & $0.079 *$ \\
\hline $\begin{array}{l}\text { Pendidikan } \\
\text { Tinggi } \\
\text { Rendah }\end{array}$ & $\begin{array}{c}21 \\
9\end{array}$ & $\begin{array}{l}70,0 \\
30,0\end{array}$ & $\begin{array}{l}16 \\
14\end{array}$ & $\begin{array}{l}53,3 \\
46,7\end{array}$ & $\begin{array}{c}22 \\
8\end{array}$ & $\begin{array}{l}73,3 \\
26,7\end{array}$ & $\begin{array}{l}59 \\
31\end{array}$ & $\begin{array}{l}65,5 \\
34,5\end{array}$ & $0.142 *$ \\
\hline $\begin{array}{l}\text { Pekerjaan } \\
\text { Bekerja } \\
\text { Tidak bekerja }\end{array}$ & $\begin{array}{l}12 \\
18\end{array}$ & $\begin{array}{l}40,0 \\
60,0\end{array}$ & $\begin{array}{l}10 \\
20\end{array}$ & $\begin{array}{l}33,3 \\
66,7\end{array}$ & $\begin{array}{l}13 \\
17\end{array}$ & $\begin{array}{l}43,3 \\
56,7\end{array}$ & $\begin{array}{l}35 \\
55\end{array}$ & $\begin{array}{l}38,2 \\
61,2\end{array}$ & $0.721 *$ \\
\hline $\begin{array}{l}\text { Status Pernikahan } \\
\text { Menikah } \\
\text { Tidak Menikah }\end{array}$ & $\begin{array}{c}28 \\
2\end{array}$ & $\begin{array}{l}93,3 \\
6,67\end{array}$ & $\begin{array}{c}25 \\
5\end{array}$ & $\begin{array}{l}83,4 \\
6,60\end{array}$ & $\begin{array}{c}27 \\
3\end{array}$ & $\begin{array}{l}90,0 \\
10,0\end{array}$ & $\begin{array}{l}80 \\
10\end{array}$ & $\begin{array}{l}88,9 \\
11,1\end{array}$ & $0.455^{*}$ \\
\hline $\begin{array}{l}\text { Pendapatan } \\
\text { Tinggi } \\
\text { Rendah }\end{array}$ & $\begin{array}{l}15 \\
15\end{array}$ & $\begin{array}{l}50,0 \\
50,0\end{array}$ & $\begin{array}{l}21 \\
90\end{array}$ & $\begin{array}{l}70,0 \\
30,0\end{array}$ & $\begin{array}{l}20 \\
10\end{array}$ & $\begin{array}{l}66,7 \\
33,3\end{array}$ & $\begin{array}{l}56 \\
34\end{array}$ & $\begin{array}{l}62,2 \\
37,8\end{array}$ & $0.066^{*}$ \\
\hline $\begin{array}{l}\text { Jenis Kanker } \\
\text { Payudara } \\
\text { Head and Neck } \\
\text { Ginekologi } \\
\text { Gastrointestinal } \\
\text { Hematologi } \\
\text { Lain-Lain }\end{array}$ & $\begin{array}{l}7 \\
7 \\
4 \\
8 \\
1 \\
3\end{array}$ & $\begin{array}{c}23,3 \\
23,3 \\
13,3 \\
26,7 \\
3,3 \\
10,0\end{array}$ & $\begin{array}{l}5 \\
3 \\
4 \\
6 \\
5 \\
7\end{array}$ & $\begin{array}{l}16,7 \\
10,0 \\
13,3 \\
20,0 \\
16,7 \\
23,3\end{array}$ & $\begin{array}{l}8 \\
9 \\
1 \\
2 \\
5 \\
5\end{array}$ & $\begin{array}{c}26,7 \\
30,0 \\
3,3 \\
6,7 \\
16,7 \\
16,7\end{array}$ & $\begin{array}{c}20 \\
19 \\
9 \\
16 \\
11 \\
15\end{array}$ & $\begin{array}{c}22,0 \\
20,0 \\
9,9 \\
17,6 \\
12,1 \\
16,5\end{array}$ & $0.189 *$ \\
\hline $\begin{array}{l}\text { Jenis Pengobatan } \\
\text { Kemoterapi } \\
\text { Radiasi } \\
\text { Pembedahan } \\
\text { Kombinasi }\end{array}$ & $\begin{array}{l}25 \\
0 \\
0 \\
5\end{array}$ & $\begin{array}{c}83,3 \\
0 \\
0 \\
16,7\end{array}$ & $\begin{array}{c}18 \\
1 \\
1 \\
10\end{array}$ & $\begin{array}{c}60,0 \\
3,3 \\
3,3 \\
33,3\end{array}$ & $\begin{array}{l}25 \\
0 \\
0 \\
5\end{array}$ & $\begin{array}{c}83,3 \\
0 \\
0 \\
16,7\end{array}$ & $\begin{array}{c}68 \\
1 \\
1 \\
20\end{array}$ & $\begin{array}{c}75,5 \\
1,1 \\
1,1 \\
22,2\end{array}$ & $0.242 *$ \\
\hline
\end{tabular}

intervensi 1 yang mendapat terapi PMR dan logoterapi, 30 orang klien kelompok intervensi 2 yang mendapat logoterapi, dan 30 orang klien kelompok kontrol sesuai dengan kriteria inklusi. Penelitian dilakukan dengan memberikan terapi PMR dan logoterapi pada kelompok intervensi 1 , logoterapi pada kelompok intervensi 2, dan pada kelompok kontrol tanpa diberikan terapi. Pretest dan posttest dilakukan pada ketiga kelompok kemudian hasilnya dibandingkan. Hasil penelitian ini meliputi karekteristik klien kanker, kecemasan, dan depresi, kemampuan relaksasi dan kemampuan menemukan makna hidup.

Tabel 1 menunjukkan bahwa sebagian besar responden adalah perempuan yaitu sebanyak $42(53,3 \%)$, pendidikan tinggi sebanyak $59(65,5 \%)$, responden yang tidak bekerja sebanyak 55 (61,2\%), responden yang menikah sebanyak $80(88,8 \%)$, dan memiliki pendapatan yang tinggi sebanyak 56 orang $(62,2 \%)$. Angka kejadian kanker yang terbanyak adalah kanker payudara yaitu sebanyak 20 kasus $(22 \%)$, dengan pengobatan terbanyak yang dijalani adalah kemoterapi sebanyak 68 (75,5\%). Hasil analisis statistik menunjukkan bahwa uji kesetaraan pada jenis kelamin, pendidikan, pekerjaaan, status pernikahan, penghasilan keluarga, jenis kanker, dan pengobatan yang dilakukan didapatkan $p$ value $\geq 0.05$ yang berarti tidak ada perbedaan yang bermakna antara ketiga kelompok atau dapat dikatakan ketiga kelompok tersebut homogen.

Tabel 2 menjelaskan bahwa rata-rata usia klien 44.5 tahun dengan usia termuda 18 tahun dan usia tertua 65 tahun. Rata-rata 
Duma Lumban Tobing: Pengaruh Progressive Muscle Relaxation dan Logoterapi

Tabel 2 Distribusi dan Analisis Kesetaraan Usia dan Lama Sakit Klien Kanker

\begin{tabular}{lllcccc}
\hline Variabel & \multicolumn{1}{c}{$\begin{array}{c}\text { Kelompok } \\
\text { Terapi }\end{array}$} & n & Mean & SD & Min-Max & $\begin{array}{c}\boldsymbol{p} \\
\text { Value }\end{array}$ \\
\hline Usia & Intervensi 1 & 30 & 43,03 & 8,624 & $18-59$ & $0.826^{*}$ \\
& Intervensi 2 & 30 & 45,60 & 9,775 & $21-61$ & \\
& Kontrol & 30 & 44,87 & 12,28 & $19-65$ & \\
& Total & 90 & 44,50 & 10,28 & $18-65$ & \\
Lama sakit & Intervensi 1 & 30 & 3,50 & 2,374 & $1-7$ & $0.177^{*}$ \\
& Intervensi 2 & 30 & 14,17 & 13,04 & $2-63$ & \\
& Kontrol & 30 & 9,23 & 6,08 & $3-36$ & \\
& Total & 90 & 11,64 & 9,16 & $2-63$ & \\
\hline
\end{tabular}

lama sakit pada klien adalah 11,64 bulan dengan responden yang baru menderita kanker dua bulan dan yang paling lama 63 bulan. Hasil uji kesetaraan menunjukkan bahwa $p$ value $\geq 0.05$ yang artinya tidak ada perbedaan yang bermakna rata-rata usia klien kanker dan lama menderita sakit pada kelompok yang mendapatkan PMR dan logoterapi, kelompok yang mendapatkan logoterapi dan kelompok kontrol. Maka dapat disimpulkan bahwa rata-rata usia klien dan lama menderita sakit pada ketiga kelompok tersebut setara atau homogen.

Tabel 3 menunjukkan $\alpha=0.05$ ada perubahan yang bermakna pada kondisi kecemasan, depresi, kemampuan relaksasi dan kemampuan menemukan makna hidup pada ketiga kelompok sebelum dan sesudah diberikan intervensi.

Tabel 4 menunjukkan rata-rata skor kecemasan setelah pemberian terapi, baik pada kelompok intervensi maupun kelompok kontrol yang tidak mendapatkan terapi apapun menunjukkan $p$ value yang lebih kecil dari 0.05 yaitu 0.000 yang berarti ada perbedaan skor yang signifikan setelah diberikan terapi. Skor rata-rata depresi setelah pemberian terapi, baik pada kelompok intervensi maupun kelompok kontrol yang tidak mendapatkan terapi apapun menunjukkan $p$ value yang lebih kecil dari 0.05 yaitu 0.002 yang berarti ada perbedaan skor yang signifikan setelah diberikan terapi. Sedangkan rata-rata skor kemampuan

Tabel 3 Analisis Perubahan Kecemasan, Depresi, Kemampuan Relaksasi dan Kemampuan Menemukan Makna Hidup Klien Kanker Sebelum dan Sesudah Diberikan Intervensi

\begin{tabular}{lllccc}
\hline Variabel & Kelompok & $\mathbf{n}$ & $\begin{array}{c}\text { Pre } \\
\text { Mean } \pm \text { SD }\end{array}$ & $\begin{array}{c}\text { Post- } \\
\text { Mean } \pm \text { SD }\end{array}$ & p-value \\
\hline Kecemasan & Intervensi 1 & 30 & $12,47 \pm 2,474$ & $9,40 \pm 1,754$ & $0.00^{*}$ \\
& Intervensi 2 & 30 & $11,77 \pm 1,675$ & $9,93 \pm 1,837$ & $0.00 *$ \\
& Kontrol & 30 & $11,17 \pm 2,394$ & $10,33 \pm 2,426$ & $0.00^{*}$ \\
Depresi & Intervensi 1 & 30 & $10,0 \pm 1,339$ & $6,73 \pm 1,337$ & $0.00 *$ \\
& Intervensi 2 & 30 & $9,93 \pm 1,982$ & $7,97 \pm 1,752$ & $0.00 *$ \\
Kemampuan & Kontrol & 30 & $10,80 \pm 1,846$ & $7,97 \pm 1,752$ & $0.01 *$ \\
Relaksasi & Intervensi 1 & 30 & $14,87 \pm 3,491$ & $22,63 \pm 2,238$ & $0.00 *$ \\
& Intervensi 2 & 30 & $17,97 \pm 2,157$ & $15,73 \pm 2,083$ & $0.00 *$ \\
Kemampuan Menemukan & Kontrol & 30 & $16,43 \pm 2,837$ & $14,87 \pm 1,995$ & $0.00 *$ \\
Makna Hidup & Intervensi 1 & 30 & $19,53 \pm 3,277$ & $21,54 \pm 4,003$ & $0.00 *$ \\
& Kontrol & 30 & $18,43 \pm 3,137$ & $21,50 \pm 3,989$ & $0.00 *$ \\
\hline
\end{tabular}


Duma Lumban Tobing: Pengaruh Progressive Muscle Relaxation dan Logoterapi

Tabel 4 Analisis Perbandingan Kecemasan, Depresi, Kemampuan Relaksasi dan Kemampuan Menemukan Makna Hidup Klien Kanker Sesudah Intervensi

\begin{tabular}{llcccc}
\hline \multicolumn{1}{c}{ Variabel } & Kemampuan & $\mathbf{n}$ & Mean & SD & p value \\
\hline Kecemasan & Intervensi 1 & 30 & 3,07 & 1,437 & $0.00^{*}$ \\
& Intervensi 2 & 30 & 1,84 & 1,234 & \\
Depresi & Kontrol & 30 & 0,84 & 1,085 & \\
& Intervensi 1 & 30 & 3,27 & 1,856 & $0.002^{*}$ \\
& Intervensi 2 & 30 & 1,96 & 1,402 & \\
Kemampuan & Kontrol & 30 & 1,97 & 1,542 & \\
Relaksasi & Intervensi 1 & 30 & 7,76 & 2,942 & $0.000^{*}$ \\
& Intervensi 2 & 30 & 2,24 & 2,986 & \\
Kemampuan Menemukan & Kontrol & 30 & 1,56 & 2,897 & \\
Makna Hidup & Intervensi 1 & 30 & 2,01 & 2,187 & $0.001^{*}$ \\
& Intervensi 2 & 30 & 3,07 & 2,345 & \\
\hline
\end{tabular}

relaksasi dan kemampuan menemukan makna hidup setelah pemberian terapi pada kelompok intervensi maupun kelompok kontrol yang tidak mendapatkan terapi apapun menunjukkan $p$ value yang lebih kecil dari 0.05 yaitu 0.000 dan 0.001 yang berarti ada perbedaan skor yang signifikan setelah diberikan terapi.

\section{Pembahasan}

Hasil penelitian menunjukkan bahwa seluruh pasien kanker dalam penelitian ini mengalami kecemasan dan depresi. Hal ini sesuai dengan hasil penelitian yang dilakukan Jadoon, Munir, Shahzad, dan Choudhry (2010); Connor, White, Kristjanson, Cousins, dan Wilkes (2010); Karabulutlu (2010); dan Permatahati dan Yusuf (2006) yang melaporkan bahwa kecemasan dan depresi adalah masalah yang paling banyak terjadi pada klien. Kecemasan dapat dialami oleh klien kanker sepanjang masa sakitnya seperti sebelum dan sesudah diagnosis ditegakkan dan saat menjalani pengobatan (Otto, 2007). Hal ini berkaitan dengan adanya ketidakpastian (uncertainty) akan prognosis penyakit, efektivitas pengobatan terhadap pemulihan kondisi yang sering ditemukan pada klien-klien kanker, terutama stadium lanjut (Shaha, 2008). Hal diatas juga didukung oleh Baradero, Dayrit dan Siswadi (2007) menyatakan ada tiga hal yang dapat memunculkan reaksi psikologis yaitu ancaman dari penyakit kanker itu sendiri, hilangnya bagian tubuh atau ancaman akan hilangnya bagian tubuh dan frustasi dalam memenuhi kebutuhan biologis karena ketidakmampuan yang diakibatkan penyakit kanker atau efek-efek dari pengobatan.

Depresi merupakan gangguan psikiatrik yang sering dialami penderita kanker dengan prevalensi $15-25 \%$ atau lebih, tergantung jenis dan stadium kankernya kira-kira 15$25 \%$ pasien kanker mengalami depresi. Depresi dapat sangat memengaruhi proses pengobatan dan penyembuhan kanker dan bila tidak ditangani dengan adekuat, akan memperburuk prognosis, meningkatkan morbiditas dan mortalitas, serta menurunkan kualitas hidup.

Hasil penelitian menunjukkan bahwa terapi PMR dan logoterapi berpengaruh dalam meningkatkan kemampuan relaksasi klien kanker. Peningkatan tertinggi ada pada kelompok yang mendapatkan PMR dan logoterapi dari $38,12 \%$ menjadi $58,02 \%$. PMR merupakan bagian dari terapi relaksasi yang digunakan sebagai suatu keterampilan koping yang mengajarkan klien kapan dan bagaimana melakukan relaksasi dan kenyamanan di bawah kondisi yang dapat menimbulkan kecemasan. Terapi ini dilakukan dengan gerakan mengencangkan dan melemaskan otot-otot pada satu bagian tubuh pada satu waktu untuk memberikan perasaan relaksasi secara fisik. Gerakan mengencangkan dan melemaskan secara progresif kelompok otot ini yang dilakukan secara berturut-turut pada 
Duma Lumban Tobing: Pengaruh Progressive Muscle Relaxation dan Logoterapi

kelompok otot utama (Snyder \& Lindquist, 2002; Kondo, dkk., 2009; Supriatin, 2010; \& Alini, 2012). Latihan PMR ini bertujuan untuk membedakan perasaan yang dialami saat kelompok otot dilemaskan dan dibandingkan ketika otot-otot dalam kondisi tegang. Dengan mengetahui lokasi dan merasakan otot yang tegang, maka klien dapat merasakan hilangnya ketegangan sebagai salah satu respon kecemasan dengan lebih jelas. Terapi PMR ini akan merangsang pengeluaran zat kimia endorfin dan enkefalin serta merangsang signal otak yang menyebabkan otot rileks dan meningkatkan aliran darah ke otak.

Efektivitas latihan relaksasi progresif adalah salah satu bentuk self control coping skill. Videbeck (2009) mengatakan bahwa individu yang memiliki koping individu dapat berada pada kecemasan yang ringan sebaliknya bila individu memiliki koping maladaptif, maka individu masuk dalam rentang kecemasan berat hingga panik. Latihan PMR rutin akan meningkatkan kemampuan klien untuk melakukan relaksasi yang nantinya akan berkontribusi terhadap penurunan kecemasan dan depresi.

Hasil penelitian menunjukkan bahwa kemampuan menemukan makna hidup pada kelompok yang mendapatkan terapi PMR dan logoterapi meningkat secara bermakna bila dibandingkan dengan kelompok klien kanker yang mendapat logoterapi dan kelompok kontrol. Taylor (2003) mengatakan penyakit kronis seperti kanker dapat mendorong seseorang untuk mencari tahu makna hidupnya. Ada beberapa alasan kenapa penyakit kanker dapat mendorong seseorang untuk mencari tahu makna hidupnya, antara lain: kanker merupakan salah satu penyakit serius bahkan dalam beberapa kasus dapat menimbulkan kematian, pengobatan penyakit ini kadang-kadang dapat menimbulkan perubahan permanen dari bentuk fisik seseorang, perubahan dalam hubungan, perubahan dalam ketertarikan, dan orang lain mungkin akan melihat penderita kanker tersebut sebagai orang yang berbeda.

Logoterapi adalah bentuk psikoterapi yang digunakan pada klien kanker untuk menemukan makna hidup dalam penderitaan yang dialaminya (Jahoda, 2000). Dengan logoterapi klien kanker diajarkan bagaimana memahami kondisi yang dialaminya kemudian diarahkan terhadap harapan yang diinginkan klien terkait dengan kondisinya dan bagaimana cara mengatasi respon yang muncul atas penderitaanya saat ini. Melalui logoterapi ini klien kanker dapat belajar pengalaman dari klien kanker lain yang memiliki kondisi yang mungkin lebih baik, sama atau bahkan lebih berat dari kondisinya. Selain itu proses pencarian makna hidup dilakukan dengan menggali kemampuan koping klien sebelumnya terhadap suatu kondisi yang dirasakan lebih berat dari kondisinya saat ini. Proses belajar menjadi lebih efektif karena langsung dipraktikkan.

Kombinasi terapi PMR dan logoterapi efektif untuk meningkatkan dan menggali kemampuan koping serta potensi yang ada dalam diri klien. Klien belajar potensi-potensi yang dimilikinya dengan kondisi yang dialaminya saat ini dan dibandingkan dengan penderitaan klien yang memilki penyakit yang sama serta membandingkan efektivitas koping yang dimiliki sebelumnya. Hal ini sesuai dengan pendapat Jahoda (2000) bahwa dengan logoterapi, klien yang menghadapi kesukaran yang menakutkan atau berada dalam kondisi yang tidak memungkinkan beraktivitas dan berkreativitas seperti pada klien kanker, dibantu untuk menemukan makna hidupnya dengan cara bagaimana ia menghadapi kondisi tersebut dan bagaimana ia mengatasinya.

Logoterapi mengajarkan kepada klien untuk melihat nilai positif dari penderitaan dan memberikan kesempatan untuk merasa bangga terhadap penderitaannya. Klien dengan kanker dalam proses adaptasinya akan mengalami banyak perubahan dalam hidupnya seperti kehilangan, kondisi kesehatan yang menurun terkait stadium penyakit, pengobatan dan terapi yang dilakukan, dan perubahan peran akibat sakit. Hal ini dapat dirasakan sebagai stresor yang akan berpengaruh terhadap makna hidupnya. Melalui logoterapi ini, klien akan dibantu menemukan dan membangkitkan kemauan untuk bermakna yang bersifat khusus dan pribadi bagi klien dimana klien dapat bertahan dalam kondisi-kondisi yang tidak menguntungkan hanya bila tujuan terpenuhi. 
Duma Lumban Tobing: Pengaruh Progressive Muscle Relaxation dan Logoterapi

Hasil penelitian ini sejalan dengan penelitian Kanin (2011) dimana terdapat pengaruh logoterapi terhadap respon ketidakberdayaan klien diabetes melitus. Penelitian lain yang mendukung hasil penelitian ini adalah penelitian yang dilakukan Kyung-Ah, dkk., (2009) tentang pengaruh logoterapi terhadap ketidakberdayaan remaja dengan kanker terminal yang menunjukkan hasil logoterapi efektif untuk mengurangi kondisi dari ketidakberdayaan atau penderitaan, mengatasi distress eksistensial, meningkatkan makna hidup, dan kualitas hidup pada remaja dengan kanker terminal.

Logoterapi mengajarkan kepada klien untuk melihat nilai positif dari penderitaan dan memberikan kesempatan untuk merasa bangga terhadap penderitaannya. Klien dengan kanker dalam proses adaptasinya akan mengalami banyak perubahan dalam hidupnya seperti proses kehilangan, kondisi kesehatan yang menurun terkait dengan stadium penyakit, pengobatan dan terapi yang dilakukan, dan perubahan peran akibat sakit. Hal ini dapat dirasakan sebagai stresor yang akan berpengaruh terhadap kebermaknaan hidup.

\section{Simpulan}

Berdasarkan hasil penelitian ini dapat disimpulkan bahwa terapi proggresive muscle relaxation dan logoterapi secara bermakna mampu meningkatkan kemampuan relaksasi dan kemampuan menemukan makna hidup serta menikmati hidup juga menurunkan kecemasan dan depresi sehingga terapi ini dapat diaplikasikan sebagai salah satu terapi spesialis jiwa di Rumah Sakit Umum.

\section{Daftar Pustaka}

Alini. (2012). Pengaruh terapi assertiveness training dan progressive muscle relaxation terhadap gejala dan kemampuan klien dengan perilaku kekerasaan di RS Dr. H. Marzoeki Mahdi Bogor. (Tesis). Tidak Dipublikasikan.

Baradero, M., Dayrit, M. W., \& Siswadi, Y. (2007). Klien gangguan sistem reproduksi dan seksualitas. Jakarta: EGC.

Bastaman, H. D. (2007). Logoterapi: psikologi untuk menemukan makna hidup dan memilih hidup bermakna. Edisi Pertama. Jakarta: Raja Grafindo Persada.

Brem, S. B. A. \& Kumar, B. N. (2011). Management of treatment-related symptoms in patient with breast cancer. Clinical Journal of Oncology Nursing, 15, 63-71.

Cheung, Y. W., Chinn, M. D., \& Pascual, A. G. (2003). Empirical exchange rate models of the nineties: are any fit to survive? Working Paper. Santa Cruz: University of California.

Connor, O. M., White, K., Kristjanson, L. J., Cousins, K., \& Wilkes, L. (2010). The prevalence of anxiety and depression in palliative care patients with cancer in Western Australia and New South Wales. MJA, 193, 544-547.

Djoerban, Z. \& Shatri, H. (2007). Masalah psikosomatik pasien kanker. Jakarta: Balai Penerbit FK UI.

Jadoon, A. N., Munir, W., Shahzad, A. M., \& Choudhry, S. Z. (2010). Assesment of depression an anxiety in adult cancer outpatient: A cross-sectional study. $B M C$ Cancer, 10, 594.

Jahoda, E. (2000). Can logoterapi help cancer patients? International Forum For Logoterapi. 89-93.

Jim, S. H., Purnell, Q. J., Richardson, A. S., Kreutz, G. D., \& Andersen, L. B. (2006). Measuring meaning in life following cancer. Qual Life Res, 15(8), 1355-1371.

Karabulutlu, Y. E., Bilici, M., Cayir, K., Tekin, B. S., \& Kantarci, R. (2010). Coping, anxiety and depression in Turkish Patients with Cancer. European Journal of General Medicine, 7, 296-302.

Kyung-Ah, K., Jae-Im, I., Hee-Sue, K., ShinJeong, K., Mi-Kyung, S., \& Songyong, S. (2009). The effect of logotheraphy on the 
Duma Lumban Tobing: Pengaruh Progressive Muscle Relaxation dan Logoterapi

suffering, finding meaning and spiritual wellbeing of adolesence with terminal cancer. Journal Korean Acad Child Health Nurs, 15(2), 136-144.

Kanin, E. (2011). Pengaruh terapi generali dan logoterapi individu terhadap respon letidakberdayaan klien diabetes meliitus di Rumah Sakit provinsi Sulawesi Utara. (Tesis). Tidak dipublikasikan.

Kondo, N., Kawachi, I., Hirai, H., Kondo, K., Subramanian, S. V., \& Hanibuchi, T. (2009). Relative deprivation and incident functional disability among older Japanese women and men: prospective cohort study. Journal of Epidemiology and Community Health, 63(6), 461-467.

Konginan. (2008). Depresi pada penderita kanker. Pusat Pengembangan Paliatif dan Bebas Nyeri RSU Dr. Soetomo Surabaya. Diakses dari www.palliative-urabaya.com.

Mhaidat, Alzoubi, H. K., Al-Sweedan, S., \& Alhusein, A. B. (2009). Prevelance of depression among cancer patients in Jourdan. Support Care Cancer, 17, 1403-1407.

Marshall, M. (2011). Prism of meaning. Guide to The Fundamental Principles of Viktor E. Frankl's Logotheraphy.

Mynatt, S. \& Cunningham, P. (2007). Unraveling anxiety and depression. Nurse Pract, 32(8), 28-36.

Permatahati, S. \& Yusuf, I. (2006). Perbandingan skor depresi pada penderita kanker serviks uteri dan penderita kanker payudara di RSUP DR. KARIADI Semarang.
Semarang: Media Medika Muda.

Shaha, M., Cox, C. L., Talman, K. \& Kelly, D. (2008). Uncertanty in breast, prostate and colorectal cancer: implication for support care. Journal of Nursing Scholarship, 40, 6067. doi: 10.1111/j.1547-5069.2007.00207.x.

Snyder, M. \& Lindquist, R. (2002). Complementary/alternative therapies in nursing. (4th ed.). New York: Springer Publishing Co.

Spiegel, D. \& Davis, J. G. (2002). Reduced emotional control as a mediator of decreasing distress among breast cancer patients in group therapy. Goteborg, Sweden: Elsevier Science.

Otto, S. (2007). Analisis mengenai dampak lingkungan. Yogyakarta: Gadjah Mada University Press.

So, W. K., Marrsh, G., Ling, M., Lo, C. K., Yeung, M., \& Li. K.H.G. (2010). Anxiety depression and quality of life among Chinese breast patients during adjuvant therapy. Euoropean Journal of Oncology Nursing, 14, 17-22.

Supriatin, L. (2010). Pengaruh terapi tought stopping dan progressive muscle relaxation terhadap ansietas pada klien dengan gangguan fisik di RSUD Dr.Soedono Madiun. (Tesis). Tidak dipublikasikan.

Taylor, S. E. (2003). Health psychology. (5th Ed.). Boston: McGraw-Hill.

Videbeck, S. L. (2009). Buku ajar keperawatan jiwa. Jakarta: EGC. 